\title{
Model Pembelajaran Daring Pada Materi Peta Geografi
}

\author{
Yuniza Ramadhani \\ E-mail: yunizaramadhani@gmail.com \\ *Program Studi Pendidikan Bahasa dan Sastra Indonesia, Universitas Riau
}

\section{Pengantar}

Pendidikan merupakan upaya yang dapat mempercepat pengembangan potensi manusia untuk mampu mengemban tugas yang di bebankan padanya, karena hanya manusia yang dapat di didik dan mendidik. Menurut hiimi mengatakan bahwa proses pembelajaran sesungguhnya memiliki peran yang sanga penting untuk meningkatkan kualitas pendidikan, sehingga pembelajaran yang akan diselenggarakan mengedepankan dan kemanfaatan bagi peserta didik. Hal tersebut diharapkan untuk menciptakan suasana pembelajaran yang dapat menstimulasi kemampuan peserta didik dalam mengeksplorasi dan menggali potensinya secara optimal dengan kreatif, inovatif, dan menyenangkan.

Belajar di rumah menyebabkan perubahan sistem pembelajaran yang awalnya tatap muka menjadi dalam jaringan (daring). Perubahan tersebut menyebabkan perubahan implementasi pembelajaran yang disusun guru berubah menjadi pembelajaran di rumah. Implementasi pembelajaran daring yang diterapkan disetiap sekolah tentunya beragam dan bukan berarti tanpa kendala, bagi sekolah yang sudah terbiasa melaksanakan pembelajaran berbasis digital bukan menjadi masalah, namun pada guru yang belum terbiasa menggunakan akan menjadi kendala (Paujiah, 2020) salah satu kendala adalah mata pelajaran yang seharusnya ada praktiknya menjadi kurang maksimal jika dilakukan dirumah saja tanpa tatap muka, salah satu yang membutuhkan praktik adalah geografi.

Perlu adanya inovasi dalam pelaksanaan kegiatan pembelajaran dengan memanfaatka berbagai media baik itu media online maupun media bentuk fisik sebagai bentuk menarik kembali perhatian peserta didik. Terlebih lagi pelajaran geografi yang bisa dikatakan sebagai pelajaran sulita yang membuthkan banyak 
praktik lansung atau kontribusi lansung peserta didik. Maka perlu dirancang kegiatan belajar geografi khusunya pada materi peta yang efektif sehingga materi dapat tersampaikan dengan maksimal.

Penulis membuat tulisan ini dengan merujuk pada pelaksanaan pembelajaran geografi pada materi peta. penulis bertujuan agar pelaksanaan pembelajaran daring dapat terlaksana dengan optimal dan memudahkan peserta didik secara individu dapat memahami materi peta secara sempurna.

\section{Tindakan yang Dilakukan}

Perlu adanya tindakan nyata agar pembelajaran peta ini dapat terlaksana dengan baik. Guru yang baik mampu menyusun model pembelajaran yang sistematis sehingga tidak terjadi penyelewengan proses dari pembelajaran. pelaksanaan kegiatan bisa itu dengan menanyakan pertanyaan ringan saat membuka kelas untuk mengecek bagaimana kesiapan pesrta didik jika terlihat peserta didik belum tertarik dengan materi bahasan tentunya guru harus sigap menciptakan inovasi agar perhatian peserta didik dapat sepenuhnya dalam menerima materi yang akan disampaikan.

Kemudian guru dapat melaksanakan curah pengalaman terkait materi peta. Guru dapat bercerita atau menarik perhatian peserta didik dengan bertnaya apa yang peserta didik ketahui terkait peta dan cara pembuatan peta. Sehingga muncul rasa ingin tahu dari peserta didik dan suasana kelas dapt terasa menyenangkan.

Kemudian Guru memperlihatkan konten video yang telah dipersiapkan dengan memanfaatkan media video maker. Sehingga akan menarik perhatian peserta didik dan peserta didik dapat memperhatikan dengan seksama materi yang ditampilkan dan penyerapan materi akan lebih mudah diterima. Karena, bentuk ilustrasi visual yang bergerak mampu menstimulus otak agar merekam video ilustarasi materi yang diberikan.

Setelah selesai video ditanyangkan selanjutnya guru akan melempar pertanyaan kepada peserta didik terkait video materi sehingga tercipta suasana belajar yang komunikatif dan menyenangkan karena sejak awal peserta didik sudah meanaruh perhatian pada materi bentuk video yang ditayangkan. 
Untuk mengukur tingkat pemahaman peserta didik guru dapat memberikan tugas kepada peserta didik dengan membuat sebuah peta sederhana dengan menggunakan kertas karkil. Nah, dari sini dapat terlihat kemampuan peserta didik dalam memahami cara pembuatan peta dalam bentuk tugas sederhana.

\section{Sarana Pendukung}

Tak hanya tindakan yang diperlukan dalam pelakanaan belajar mengajar, tetapi sarana pendukung yang juga turut menjadi unsur penting dalam menciptakan suasana pembelajaran yang efektif pada mata pelajaran bahasa Indonesia. Sarana pendukung tersebut antara lain:

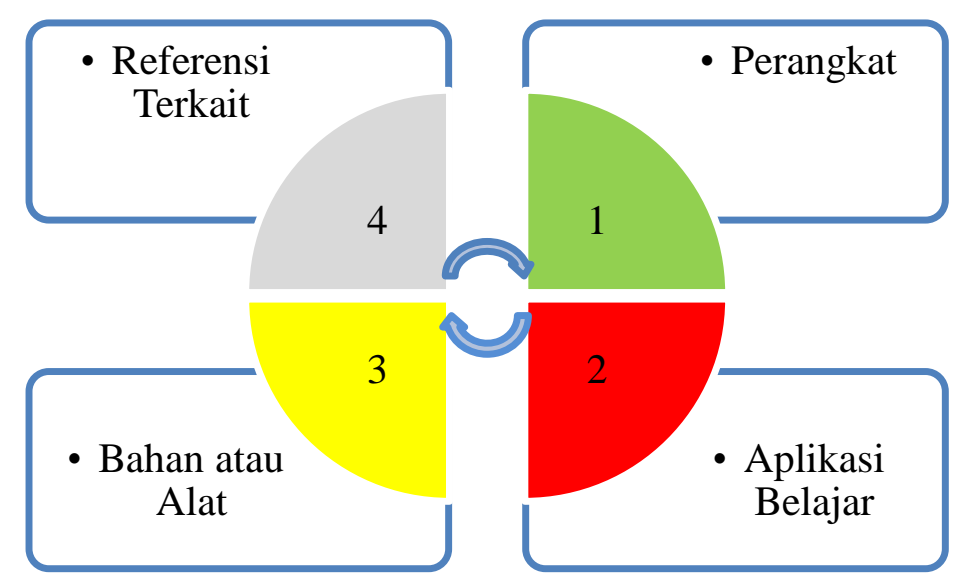

Gambar 1. Sarana Pendukung Pembelajaran Geografi Materi Peta.

1. Perangkat, dalam pelaksanaan pembelajaran daring perangkat merupakan saran pertama yang harus di siapkan seorang tengana pendidik, perangkat ini dapat berupa computer atau laptop, kuota internet serta jaringan internet yang memadai. Sehingga proses pembelajaran dapat terlaksana dengan baik.

2. Aplikasi Belajar, penggunaan aplikasi merupakan sarana umum yang sering digunakan guru dalam melaksanakan kegiatan pembelajaran, dapat berupa aplikasi Google classroom, Google meet atau zoom.

3. Bahan atau Alat yang digunakan dalam meunjang proses pembalajaran peta pada pelajaran geografi ialah kertas karkil. Karena dalam pemberian tugas kepada peserta didik menggunakan kertas karkil untuk membuat peta sederhana. 
Referensi terkait menjadi saran pendukung dalam penguatan materi kepada peserta didik. Peserta didik dapat menggunakan buku-buku ataupun mencari diinternet. Sehingga pembelajaran tidak dilaksanakan dikelas saja, tetapi juga diluar kelas.

\section{Tindakan Solutif}

Selain sarana pendukung, guru bahasa Indonesia harus mampu sigap dalam menghadapai kendala dalam proses pelaksanaan pembelajaran . Guru harus mampu menyiapkan solusi terhadap kemungkinan-kemungkinan yang dapat menjadi penghalang dalam proses pembelajaran. Adapun tindakan solutf anatara lain:

1. Menggunakan Whatssapp atau aplikasi sejenis untuk mengabari peserta didik.

2. Memanfaatkan website terkait materi peta.

3. Memanfaatkan ataupun menggunakan wifi gratis yang tersedia disekitar guru ataupun peserta didik yang terkendala.

4. Menggunakan buku atau model maupun media atlas atau globe sebagai ilustrasi memudahkan peserta didik.

\section{Simpulan}

Pembelajaran geografi khusunya dalam materi peta perlu ditemukan model pembelajaran yang efektif sehingga peserta didik dapat menerima materi secara optimal. Dalam pelaksanaan pembelajaran teks tanggapan dapat dengan tindakan mempersiapkan pendidik dan peserta didik, melakukan curah pengalaman terkait materi peta dan cara pembuatan peta, memberikan video konten edukasi terkait materi peta, serta memberikan tugas membuat peta sederhana kepada peserta didik.

Selain dibarengi tindakan juga harus mempersiapkan sarana pendukung dan penyelesaian saat menemukan kendala dalam proses pelaksanaan pembelajaran. Saran pendukung antara lain perangkat, aplikasi belajar, bahan atau alat, dan referensi terkait dengan materi peta. Namun, pasti akan menemukan kendala terkait sarana pendukung tersebut, menggunakan Whatssapp atau aplikasi 
sejenis untuk mengabari peserta didik, memanfaatkan website terkait materi peta, memanfaatkan ataupun menggunakan wifi gratis yang tersedia disekitar guru ataupun peserta didik yang terkendala, menggunakan buku atau model maupun media atlas atau globe sebagai ilustrasi memudahkan peserta didik.

\section{Referensi}

Azizah, T. F., Hastuti, K. P., \& Rahman, A. M. (2021). Persepsi Guru Geografi Mengenai Pemanfaatan Aplikasi Pembelajaran Daring Sebagai Media Pembelajaran Di SMA/MA Se Kecamatan Banjarmasin Utara. JPG (Jurnal Pendidikan Geografi), 8(1).

Fahmi, L. A. (2021). Implementasi Pembelajaran Daring Guru Geografi Pada Masa Covid 19 (Doctoral dissertation, Universitas Muhammadiyah Surakarta).

Mustafa, M. N., \& Zulhafizh, Z. (2018). Information Mastery By Teachers As A Strategy To Succeed In The Implementation Of Teaching And Learning Activities. In International Seminar and Annual Meeting BKS-PTN Wilayah Barat 2018 (pp. 516-523), Palembang.

Mustafa, M. N., \& Zulhafizh. (2017). Building the Professionalism of Teachers as an Effort to Improve Education. In Husein, R, et al (Eds.), International Seminar and Annual Meeting 2017 Fields of Linguistics, Literature, Arts, and Culture, Medan, 449.

Widhiarto, B. S., Noviasari, A., \& Rahmawati, T. (2020). Problematika Pembelajaran Daring Geografi melalui Google Classroom di SMA N 1 NGUTER. Edudikara: Jurnal Pendidikan dan Pembelajaran, 5(4), 197206. 


\section{*Data Penulis}

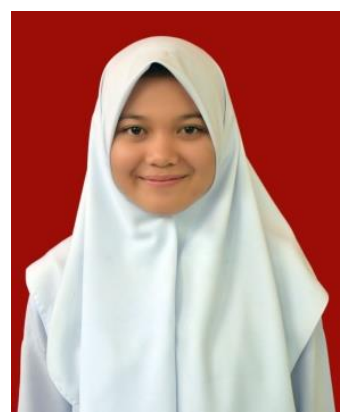

Yuniza Ramadhani, lahir di Perk. Sei Lala, 17 November 2001. Pada tahun akademik 2020-2021 Ia melanjutkan studi pada strata satu Jurusan Pendidikan Bahasa dan Seni di Program Studi Pendidikan Bahasa dan Sastra Indonesia FKIP Universitas Riau melalui jalur SMMPTN-BARAT, dan sampai sekarang masih berstatus mahasiswa.

Kontak:

Hp/WA : + 6283273083530

Email : yunizaramdhani@gmail.com 